\title{
Perbedaan Jumlah Leukosit pada Pasien Kanker Payudara Pasca Bedah Sebelum dan Sesudah Radioterapi
}

\author{
Rizqy Auliya Lubis ${ }^{1}$, Efrida $^{2}$, Dwitya Elvira ${ }^{3}$
}

\begin{abstract}
Abstrak
Radioterapi merupakan salah satu modalitas terapi kanker payudara. Radioterapi dapat menekan sistem hematopoetik pada sumsum tulang dengan efek akut berupa penurunan jumlah leukosit (leukopenia) yang memengaruhi prognosis pasien. Tujuan penelitian ini adalah menentukan perbedaan jumlah leukosit pasien kanker payudara pasca bedah sebelum dan sesudah radioterapi. Desain penelitian ini adalah analitik potong lintang. Populasi dalam penelitian ini merupakan seluruh data rekam mmedik pasien kanker payudara pasca bedah sebelum dan sesudah radioterapi di bagian Radioterapi RSUP Dr. M. Djamil Padang periode 2014-2016. Penelitian ini dilakukan dengan teknik total sampling pada 31 pasien kanker payudara dengan analisis statistik uji t berpasangan. Uji statistik bermakna jika $p<0,05$. Subjek penelitian pasien kanker payudara memiliki rentang usia paling banyak 40-49 tahun $(51,6 \%)$, sedangkan kanker payudara dominan berlokasi di payudara kiri $(51,6 \%)$ dengan stadium terbanyak ditemukan yaitu stadium III (41,9\%). Rerata jumlah leukosit sebelum radioterapi sebanyak $8015 / \mathrm{mm}^{3}$, sedangkan rerata jumlah leukosit sesudah radioterapi sebanyak $6256 / \mathrm{mm}^{3}$. Hasil penelitian menunjukkan bahwa terdapat perbedaan jumlah leukosit yang bermakna secara statistik pada pasien kanker payudara pasca bedah sebelum dan sesudah radioterapi.
\end{abstract}

Kata kunci: kanker payudara, leukosit, radioterapi

\section{Abstract}

Radiotherapy is one of modality in breast cancer therapy. Radiotherapy can suppress hematopoietic system in bone marrow causing acute effects such as decrease in leukocyte count (leukopenia) that affect the prognosis of patients. The objective of this study was to determine differences between leukocytes count of post-operative breast cancer patients before and after radiotherapy. The design of this study was cross-sectional. The population in this study was medical record of post-operative breast cancer patients before and after radiotherapy in Radiotherapy Department of Dr. M. Djamil Hospital Padang during 2014 - 2016. This study was using a total sampling technique in 31 breast cancer patients with paired $T$ test statistical analysis. Test statistically significant when $p<0.05$. The subject of this study of breast cancer patients had an age range of 40-49 years at most (51.6\%), whereas breast cancer were predominantly located in the left breast (51.6\%) and stage III mostly found in breast cancer patients (41,9\%). The mean number of leukocytes before radiotherapy was $8015 / \mathrm{mm}^{3}$, while the average number of leukocytes after radiotherapy was $6256 / \mathrm{mm}^{3}$. The results showed that there were statistically significant differences number of leukocytes in patients with post-operative breast cancer before and after radiotherapy.

Keywords: breast cancer, leukocyte, radiotherapy

Affiliasi penulis: 1. Prodi Profesi Dokter FK Unand (Fakultas Kedokteran Universitas Andalas Padang), 2.Bagian Patologi Klinik FK Unand/RSUD M Djamil Padang, 3. Bagian IImu Penyakit Dalam FK Unand.
Korespondensi: Rizqy Auliya Lubis email: rizqylubis2605@gmail.com Telp: 081266907441 


\section{PENDAHULUAN}

Kanker payudara sebagai kanker terbanyak pada perempuan di dunia dan kanker penyebab kematian terbanyak pada perempuan setelah kanker paru. ${ }^{1,2}$ Penelitian pada tahun 2012 melaporkan sebanyak 1,7 juta perempuan menderita kanker payudara. ${ }^{3}$ Kanker payudara juga merupakan kanker terbanyak di Indonesia. ${ }^{4}$ Registrasi Nasional Kanker Indonesia melaporkan sebanyak 18,6\% kanker pada perempuan Indonesia adalah kanker payudara. ${ }^{5}$ Prevalensi kanker payudara pada perempuan di Sumatera Barat sebanyak $0,9 \%$ melebihi angka kejadian nasional kanker payudara yang hanya $0,5 \% .{ }^{6}$

Angka kematian akibat kanker payudara sangat tinggi. Penelitian pada tahun 2012 melaporkan angka kematian akibat kanker payudara pada perempuan di dunia mencapai 522.000 jiwa. $^{3}$ Risiko kematian akibat kanker payudara dapat ditekan dengan radioterapi dari $25,2 \%$ menjadi $21,4 \%$ dalam 15 tahun. $^{7}$

Radioterapi dilakukan jika telah memenuhi kriteria radioterapi pasca bedah menurut National Comprehensive Cancer Network (NCCN) yaitu ukuran tumornya lebih dari $5 \mathrm{~cm}$, batasan sayatan dekat, atau metastasis pada satu atau lebih kelenjar limfe dengan atau tanpa radioterapi pada kelenjar limfe aksila dan supra/infraklavikula. ${ }^{8}$ Radioterapi juga dapat menurunkan risiko rekurensi kanker dalam 10 tahun dari $35 \%$ menjadi $19,3 \%$, sehingga rekurensi kanker payudara pasca bedah (mastektomi atau operasi konservasi payudara) pada dinding dada yang tinggi (44\%-69\%) dapat diturunkan. ${ }^{7,9}$

Radioterapi dapat menyebabkan penekanan sumsum tulang, sehingga terjadi pansitopenia perifer yang menyebabkan anemia dan leukopenia. ${ }^{10} \mathrm{Hal}$ ini dijelaskan dengan penelitian Khadim (2013) bahwa pada pasien kanker payudara yang menjalani radioterapi, jumlah leukosit berbanding terbalik dengan kenaikan dosis radioterapi dan akan stabil pada dosis 36 Gy. Dosis yang berkisar antara 18-36 Gy menyebabkan penurunan efisiensi sumsum tulang yang berakibat pada penurunan jumlah leukosit. ${ }^{11}$

Radioterapi ke - 15 terbukti menyebabkan peningkatan produksi radikal bebas dan menurunnya aktivitas mekanisme pertahanan antioksidan yang menyebabkan stres oksidatif, sehingga efek toksik pada sumsum tulang lebih berat khususnya leukopenia dibandingkan sebelum radioterapi. ${ }^{12}$

Leukopenia dapat terjadi setelah radioterapi, karena sel leukosit sangat radiosensitif. ${ }^{13}$ Dampak terjadinya leukopenia akibat radioterapi tersebut yaitu menurunnya imunitas tubuh, karena leukosit berperan memfagosit patogen yang masuk kedalam tubuh. Leukopenia yang timbul akan memperburuk prognosis pasien kanker. ${ }^{14,15}$

Hasil penelitian dari Nisa (2014) menunjukkan produksi leukosit pada kanker payudara yang melakukan radioterapi menurun sebanyak $38,93 \%{ }^{16}$ Penelitian tentang perbedaan jumlah leukosit pada pasien kanker payudara pasca bedah sebelum dan sesudah radioterapi belum pernah dilakukan di RSUP Dr. M. Djamil Padang. Penelitian ini juga dapat mempelajari hubungan leukopenia akibat radioterapi terhadap prognosis pasien kanker payudara. Oleh karena itu, penulis tertarik meneliti di RSUP Dr. M. Djamil Padang tentang perbedaan jumlah leukosit pada pasien kanker payudara pasca bedah sebelum dan sesudah radioterapi.

\section{METODE}

Jenis penelitian ini adalah studi analitik dengan desain potong lintang. Penelitian ini dilaksanakan pada Juli 2016 - Maret 2017 di bagian Radioterapi RSUP Dr. M. Djamil Padang. Sampel penelitian ini yaitu seluruh data rekam medic penderita kanker payudara di bagian Radioterapi RSUP Dr. M. Djamil Padang pada Januari 2014 - Desember 2016 dengan kriteria inklusi berupa pasien kanker payudara semua stadium (0, 1, 2, 3, dan 4) pasca bedah yang menjalani radioterapi dan pasien kanker payudara berjenis kelamin perempuan, serta kriteria eksklusi yaitu pasien dengan data rekam medis (usia, lokasi kanker, stadium kanker dan hasil laboratorium hematologi sebelum dan sesudah radioterapi) yang tidak lengkap dan pasien kanker payudara yang menjalani kemoterapi. 
HASIL

Tabel 1.Karakteristik subjek penelitian

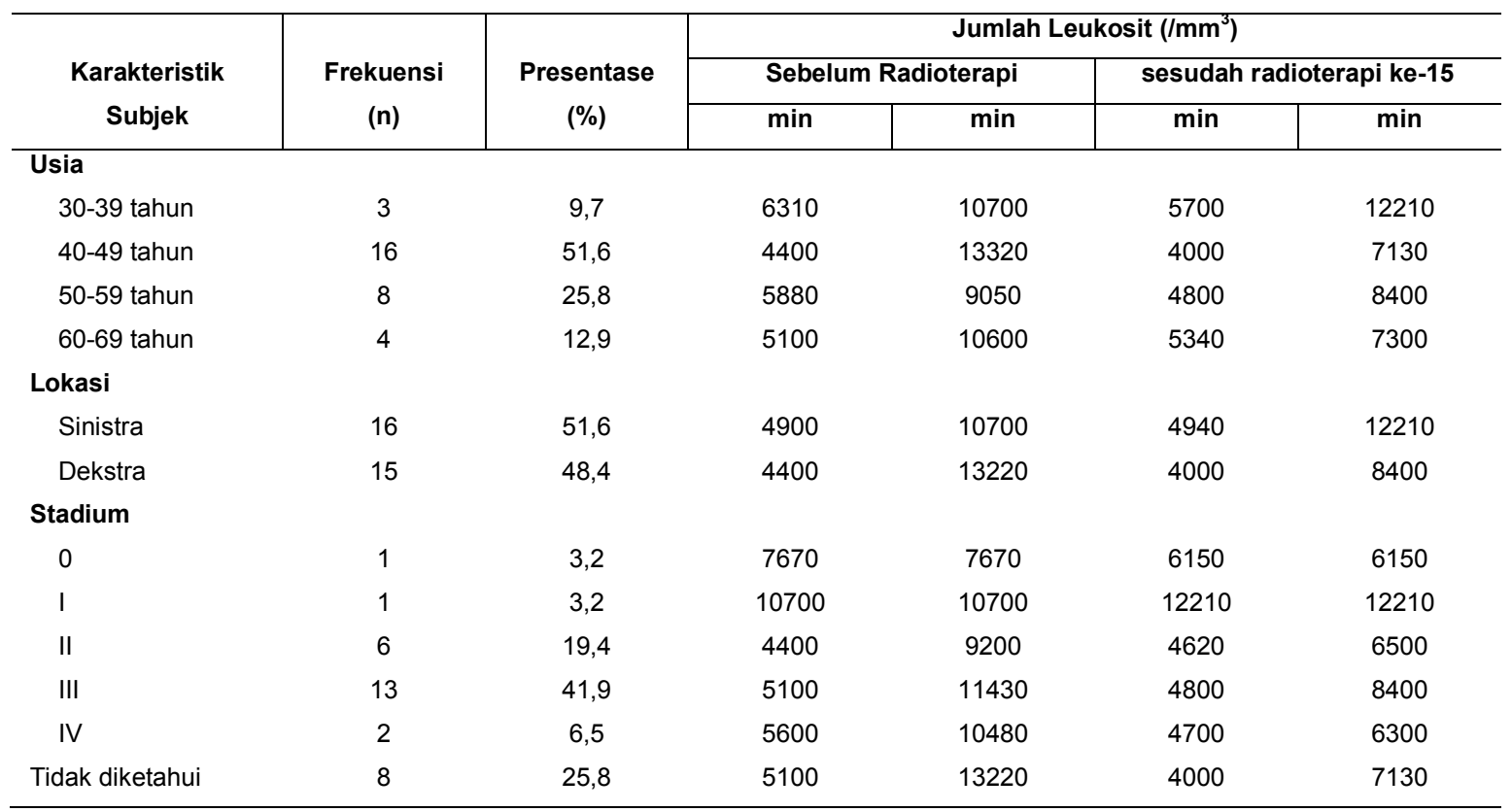

Tabel di atas menjelaskan bahwa pasien kanker payudara pasca bedah yang menjalani radioterapi paling banyak berusia rentang 40-49 tahun sebanyak 51,6\%. Pasien kanker payudara pasca bedah yang menjalani radioterapi sebagian besar berlokasi di sinistra sebanyak $51,6 \%$. Sebagian besar pasien kanker payudara pasca bedah yang menjalani radioterapi berada pada stadium 3 sebanyak $41,9 \%$.

Tabel 2. Perbedaan jumlah leukosit pada pasien kanker payudara pasca bedah sebelum dan sesudah radioterapi

\begin{tabular}{lcc}
\hline \multicolumn{1}{c}{ Leukosit } & $\begin{array}{c}\text { Rerata } \pm \text { SD } \\
\left(/ \mathrm{mm}^{3}\right)\end{array}$ & Nilai $\mathbf{p}$ \\
\hline $\begin{array}{l}\text { Sebelum } \\
\text { Radioterapi }\end{array}$ & $8015 \pm 2056$ & \\
Sesudah & $6256 \pm 1543$ & 0.000 \\
Radioterapi ke-15 & & \\
Perbedaan rerata & $1759 \pm 1818$ & \\
\hline
\end{tabular}

Data telah mengalami uji normalitas ShapiroWilk karena jumlah sampel pada penelitian ini kurang dari 50 sampel. Uji Shapiro-Wilk menunjukkan data jumlah leukosit sebelum radioterapi terdistribusi normal dengan nilai $p=0,698$ (normal: $p>0,05$ ), sedangkan data jumlah leukosit sesudah radioterapi ke-15 tidak terdistribusi normal dengan nilai $p=0,001$, sehingga dilakukan transformasi data. Hasil transformasi data lalu diuji kembali dengan uji ShapiroWilk menunjukkan data jumlah leukosit sesudah radioterapi ke-15 telah terdistribusi normal dengan nilai $p=0,185$. Data jumlah leukosit sebelum dan sesudah radioterapi ke-15 kemudian diuji statistik dengan uji $T$ berpasangan didapatkan nilai $p=0,000$ yang menunjukkan perbedaan jumlah leukosit pada radioterapi secara bermakna.

\section{PEMBAHASAN}

\section{Analisis Univariat}

\section{Distribusi Kelompok Usia Kanker Payudara}

Hasil penelitian ini menunjukkan bahwa pasien kanker payudara terbanyak pada kelompok usia 40-49 tahun sebesar $51,6 \%$, kemudian pada kelompok usia 50-59 tahun sebesar $25,8 \%$, disusul dengan kelompok usia 60-69 tahun sebesar 12,9\%. Berbeda dengan kelompok usia 30-39 tahun sebesar 9,7\%.

Hasil ini sejalan dengan penelitian Setyowati (2012) menunjukkan bahwa pasien kanker payudara sebagian besar berusia 40-49 tahun sebanyak $55,3 \% .{ }^{17}$ Berbeda dengan penelitian Rahmatya et al (2015) yang menunjukkan bahwa pasien penderita 
kanker payudara sebagian besar berusia $\geq 40$ tahun $(78,3 \%)$ dan kelompok usia $<50$ tahun sebanyak $67,4 \%{ }^{18}$

Perbedaan cara pengelompokan usia pasien kanker payudara tergantung pada perbedaan lokasi, subjek, pengelompokkan usia, waktu penelitian. Penelitian Rahmatya (2015) pada pasien kanker payudara di bagian bedah RSUP Dr. M. Djamil Padang periode Januari 2012-Desember 2012 menggunakan 46 sampel. Penelitian ini hanya mengelompokkan usia pasien kanker payudara menjadi $<40$ tahun, $\geq 40$ tahun, $<50$ tahun, dan $\geq 50$ tahun. $^{18}$

Pasien kanker payudara terbanyak pada usia 40-49 tahun diduga karena memasuki usia pramenopause. Pada masa ini hormon progesteron tidak dapat dihasilkan dalam jumlah yang cukup, oleh karena itu produksi hormon estrogen tidak dapat ditekan, sehingga dapat memicu kanker payudara. ${ }^{19}$

Peningkatan risiko kanker payudara sesuai dengan peningkatan usia berhubungan angka harapan hidup. ${ }^{20} \mathrm{Hal}$ ini didasarkan karena semakin tinggi usia, maka semakin banyak juga kadar dan durasi terpaparnya hormon estrogen. ${ }^{21} \mathrm{Hal}$ ini sesuai dengan penelitian Suzuki et al (2005) yang menunjukkan bahwa hormon estrogen juga diproduksi secara lokal pada jaringan kanker payudara, dibuktikan dengan adanya peningkatan bermakna kadar estradiol (salahsatu jenis estrogen) sebesar 2,3 kali lebih tinggi pada jaringan tumor dibandingkan jaringan sehat. ${ }^{22}$

\section{Distribusi Lokasi Kanker Payudara}

Hasil penelitian ini menunjukkan bahwa kanker payudara lebih banyak ditemukan di payudara sinistra sebesar $51,6 \%$ dibandingkan dengan payudara dekstra yang hanya $48,4 \%$.

Hal ini sejalan dengan penelitian Amer (2014) juga melaporkan bahwa kanker payudara dominan pada payudara sinistra dengan rasio insidensi payudara sinistra dengan dekstra sebesar 1,1 yang ditemukan pada semua kelompok usia kecuali rentang usia 50-59 tahun, kurang dari 30 tahun, dan lebih dari 90 tahun. $^{23}$

Kanker payudara lebih sering di payudara sinistra belum diketahui pasti penyebabnya, tetapi diduga karena ukuran payudara sinistra lebih besar yang diakibatkan oleh payudara sinistra memiliki lebih banyak jaringan dibandingkan payudara dekstra. Jaringan yang lebih banyak meningkatkan kepadatan payudara yang dapat meningkatkan risiko kanker payudara. $^{24}$ Penelitian tentang ukuran payudara perempuan yang diukur dengan mammografi menunjukkan bahwa pada $55 \%$ perempuan sehat ditemukan payudara sinistra lebih besar daripada payudara dekstra. Hipertrofi payudara dan perkembangan kanker juga lebih sering ditemukan pada payudara sinistra. ${ }^{23}$

Kanker payudara sinistra yang menjalani radioterapi memiliki risiko lebih tinggi mengalami komplikasi kardiovaskular seperti stroke dan infark miokard yang diakibatkan oleh radiasi berulang di daerah jantung dan karotis. ${ }^{25}$

\section{Distribusi Stadium Kanker Payudara}

Hasil penelitian ini menunjukkan pasien kanker payudara pasca bedah yang menjalani radioterapi terbanyak ditemukan dalam stadium III $(41,9 \%)$, disusul dengan stadium II (19,4\%), kemudian stadium IV (6,5\%), stadium 0 dan I dengan persentase sama $(3,2 \%)$, akan tetapi jumlah pasien kanker payudara yang tidak diketahui stadiumnya juga cukup besar yaitu sebesar $25,8 \%$. Hasil ini didukung oleh penelitian Sinaga (2015) menunjukkan pasien kanker payudara sebagian besar ditemukan pada stadium III yaitu sebesar $49 \% .{ }^{26}$ Berbeda dengan hasil penelitian Jung et al. (2015) yang menunjukkan kanker payudara paling banyak ditemukan pada stadium I sebanyak $40,4 \%{ }^{27}$

Pengelompokan stadium ini sangat penting untuk menentukan prognosis kanker payudara yang dinyatakan dalam five years- survival rate. Persentase five years- survival rate berbanding terbalik dengan stadium kanker payudara saat ditemukan. Semakin rendah five years-survival rate, maka semakin tinggi/lanjut stadium kanker payudara saat ditemukan. Penelitian pada semua ras, pada stadium lokal (stadium I dan sebagian stadium II) memiliki five years-survival rate sebesar 99\%, sedangkan pada stadium regional (stadium II dan III tergantung pada limfe nodus yang terlibat) memiliki five years-survival 
rate sebesar $84 \%$, dan pada stadium lanjut (stadium IIIC dan IV) memiliki five years-survival rate hanya sebesar $24 \%{ }^{20}$

\section{Analisis Bivariat}

Hasil uji statistik dengan uji $\mathrm{t}$ berpasangan menunjukkan terdapat perbedaan bermakna jumlah leukosit pada pasien kanker payudara pasca bedah sebelum dan sesudah radioterapi dengan nilai $p=$ $0,000(p<0,05)$ dengan perbedaan jumlah leukosit berupa penurunan jumlah leukosit sebesar $21,94 \%$.

Hasil ini juga sejalan dengan penelitian Dovšak et al (2009) yang menunjukkan terjadinya perbedaan jumlah leukosit berupa penurunan dari 9060/mm menjadi $7160 / \mathrm{mm}^{3}$ pada pasien kanker intraoral lanjut pasca bedah yang menjalani radioterapi. ${ }^{28} \mathrm{Hal}$ ini membuktikan bahwa jumlah leukosit setelah radioterapi menurun tidak hanya pada pasien kanker payudara, tetapi juga pada pasien kanker lainnya.

Penurunan leukosit (leukopenia) berhubungan erat dengan prognosis pasien kanker payudara. Hal ini sesuai dengan penelitian Amadori et al. (2010) bahwa pasien dengan leukopenia grade tinggi setelah terapi memiliki prognosis yang lebih baik, karena membuktikan adanya efek biologis terapi pada tumor berupa penekanan sumsum tulang. Berbeda halnya dengan leukopenia yang sedikit, menandakan tidak adanya atau lemahnya efek biologis terapi terhadap tumor. $^{29}$

Radiasi juga dapat mengaktifkan sistem imun dan meningkatkan presentasi antigen pada sel tumor yang meningkatkan efek anti tumor. Efek anti tumor radioterapi ditunjukkan dengan peningkatan kerentanan sel tumor dibandingkan sel normal terhadap kerusakan DNA akibat paparan radiasi berulang. Sel normal memiliki kemampuan perbaikan DNA yang lebih baik dibandingkan dengan sel tumor, kemudian akumulasi kerusakan DNA yang cukup di dalam sel tumor menyebabkan kematian sel. Radiasi selain memiliki efek langsung untuk membunuh sel kanker, juga memiliki efek tidak langsung dalam menstimulasi respons imun anti tumor yang lebih efektif. $^{30}$

Radiasi juga menyebabkan menurunnya sistem imun/imunosupresi sesuai dengan penelitian
Chow et al (2015) bahwa radiasi pada pasien kanker payudara menyebabkan imunosupresi yang ditandai dengan penurunan absolut pada jumlah total sel $\mathrm{T}$, penurunan relatif sel T/populasi sel penginduksi imun, dan peningkatan relatif sel $\mathrm{T}$ helper/ populasi sel sitotoksik. Imunosupresi berat berkaitan erat dengan tampilan klinis akhir pasien kanker, tetapi mekanisme biologisnya belum dapat dijelaskan. Beberapa penelitian menunjukkan imunosupresi mengakibatkan meningkatnya progresifitas tumor dan menurunnya angka ketahanan hidup, sehingga prognosis tumor memburuk. Terapi tambahan lain seperti imunoterapi dan peningkatan kondisi fisik berupa perbaikan gizi individu diperlukan agar efek imunosupresi ini dapat diimbangi. $^{30}$

\section{SIMPULAN}

Jumlah leukosit pasien kanker payudara pasca bedah sebelum radioterapi menunjukkan rerata normal sesuai dengan nilai acuan.

Jumlah leukosit pasien kanker payudara pasca bedah sesudah radioterapi mengalami penurunan rerata dibandingkan dengan rerata leukosit sebelum radioterapi, tetapi masih dalam nilai normal sesuai dengan nilai acuan.

Terdapat perbedaan bermakna jumlah leukosit pasien kanker payudara pasca bedah sebelum dan sesudah radioterapi.

\section{DAFTAR PUSTAKA}

1. Colditz GA, Bohlke K, Berkey CS. Breast cancer risk accumulation starts early: Prevention must also. Breast Cancer Res Treat. 2014;145(3):56779.

2. De Santis C, Ma J, Bryan L, Jemal A. Breast cancer statistics, 2013. Ca Cancer J Clin. 2014;64: 52-62.

3. International Agency of Research on Cancer. Latest world cancer statistics global cancer burden rises to 14.1 million new cases in 2012: Marked increase in breast cancers must be addressed. Lyon: International Agency of Research on Cancer. 2013.

4. Iskandarsyah A, Klerk C, Suardi DR, Sadarjoen SS, Passchier J. Consulting a traditional healer 
and negative illness perceptions are associated with non-adherence to treatment in Indonesian women with breast cancer. Psycho-Oncology. 2014; 23: 1118-1124.

5. Kementerian Kesehatan RI. Info pusat data dan informasi kementerian kesehatan RI. Jakarta: Pusdatin Kementerian Kesehatan RI. 2015.

6. Kementerian Kesehatan RI. Riset kesehatan dasar. Jakarta: Badan Penelitian dan Pengembangan Kesehatan Kementrian Kesehatan RI. 2013.

7. Lancet. Effect of radiotherapy after breastconserving surgery on 10-year recurrence and 15year breast cancer death: meta-analysis of individual patient data for 10801 women in randomised trials. Lancet. 2011;378(9804):170716.

8. Aditya E, Gondhowiardjo SA. Hipofraksinasi pada kanker payudara stadium dini. Radioterapi \& Onkologi Indonesia. 2013;4(2):53-60.

9. Wang $Q$, Ye T, Chen HL, Zhang XG, Zhang LZ. Correlation between intensity modulated radiotherapy and bone marrow suppression in breast cancer. European Review for Medical and Pharmacological Sciences. 2016;20:75-81.

10. Lamas DJM, Carabajal E, Prestifilippo JP, Rossi L, Eleverdin JC, Merani S, et al. Protection of radiation-induced damage to the hematopoietic system, small intestine and salivary glands in rats by JNJ7777120 compound, a histamine H4 ligand. Plos One. 2013;8(7):1-13.

11. Khadim AA. Effect of gamma radiation in cellular compound of blood for patients with breast cancer. Int. J. of Multidisciplinary and Current research. 2013;208-10.

12. Novirianthy R, Sekarutami SM. Pengaruh kadar malondialdehyde dan aktivitas antioksidan enzimatik catalase terhadap toksisitas akut radiasi pada kanker serviks stadium lanjut lokal. Radioterapi \& Onkologi Indonesia. 2015;6(2):8192.

13. Setyawan A, Djakaria HM. Efek dasar radiasi pada jaringan. Radioterapi \& Onkologi Indonesia. 2014; 5(1):25-33.
14. Campbell NA, Reece JB, Urry LA, Cain ML, Wasserman SA, Jackson RB, et al. (2011). Campbell biology. Edisi ke 9. San Fransisco: Pearson Education, Inc. 2011.

15. Aminullah, Wiratno, Susilaningsih N. Pengaruh kombinasi vitamin $\mathrm{C}$ dan $\mathrm{E}$ dosis tinggi terhadap sistem hemopoetik penderita kanker kepala dan leher yang mendapat kemoterapi cisplatin. Med Hosp. 2012;1(2):89-94.

16. Nisa AK. Efek radioterapi terhadap produksi sel darah pada penderita ca mammae dan ca cervix. Student Journal Universitas Brawijaya. 2014.

17. Setyowati I. Hubungan antara pengetahuan, sikap dan perilaku pencegahan dengan kejadian kanker payudara di RSUD Dr. Moewardi. Universitas Muhammadiyah Surakarta; 2012 (diunduh Feb 2017). Tersedia dari: URL: HYPERLINK http://eprints.ums.ac.id/22307/20/NASKAH PUBL IKASI.pdf

18. Rahmatya A, Kambri D, Mulyani H. Hubungan usia dengan gambaran klinikopatologi kanker payudara di bagian bedah RSUP Dr. M. Djamil Padang. Jurnal Kesehatan Andalas. 2015;4(2):478-84.

19. Surbakti E. Hubungan riwayat keturunan dengan terjadinya kanker payudara pada ibu di RSUP $\mathrm{H}$. Adam Malik Medan. Jurnal Precure. 2013;1(1):15 21.

20. American Cancer Society. Breast Cancer Facts \& Figures 2015-2016. Atlanta: American Cancer Society, Inc; 2015.

21. Setyowati I. Hubungan antara pengetahuan, sikap dan perilaku pencegahan dengan kejadian kanker payudara di RSUD Dr. Moewardi. Universitas Muhammadiyah Surakarta; 2012 (diunduh Februari 2017). Tersedia dari: URL: HYPERLINK http://eprints.ums.ac.id/22307/20/NASKAH PUBL IKASI.pdf

22. Suzuki T, Miki $\mathrm{Y}$, Nakamura $\mathrm{Y}$, Moriya T, Ito $\mathrm{K}$, Ohuchi $\mathrm{N}$, et al. Sex steroid-producing enzymes in human breast cancer. Endocrine-Related Cancer. 2005;12:701-20.

23. Amer MH. Genetic factors and breast cancer laterality. Cancer Management and Research. 2014;6:191-203. 
24. Perkins Cl, Hotes J, Kohler BA, Howe HL. Association between breast cancer laterality and tumor location, United States, 1994-1998. Cancer Causes Control. 2004;15(7):637-45.

25. Haque R, Yood MU, Geiger AM, Kamineni A, Avila CC, Shi J, et al. Long-term safety of radiotherapy and breast cancer laterality in older survivors. Cancer Epidemiol Biomarkers Prev. 2011;20(10): 2120-6.

26. Sinaga LE, Muda S, Rasmaliah. Karakteristik penderita kanker payudara yang dirawat inap di RS St. Elisabeth Medan tahun 2011 - 2013. 2015 (diunduh Februari 2017). Tersedia dari: URL: HYPERLINK

http://download.portalgaruda.org/article.php?article $=299225 \& \mathrm{val}=4108 \&$ title=KARAKTERISTIK\%20PE NDERITA\%20KANKER\%20PAYUDARA\%20YAN G\%20DIRAWAT\%20INAP\%20DI\%20RS\%20St.\% 20ELISABETH\%20MEDAN\%20TAHUN\%2020112013.

27. Jung HA, Park YH, Kim M, Kim S, Chang WJ, Choi $\mathrm{MK}$, et al. Prognostic relevance of biological subtype overrides that of TNM staging in breast cancer: discordance between stage and biology. Tumor Biol. 2015;36:1073-9.

28. Dovšak T, Ihan A, Didanovič V, Kansky A, Hren NI. Influence of surgical treatment and radiotherapy of the advanced intraoral cancers on complete blood count, body mass index, liver enzymes and leukocyte CD64 expression. Radiol Oncol. 2009; 43(4): 282-92.

29. Amadori D, Silvestrini R, Lena M, Boccardo $F$, Rocca A, Scarpi E, et al. Randomized phase III trial of adjuvant epirubicin followed by cyclophosphamide, methotrexate, and 5-uorouracil (CMF) versus CMF followed by epirubicin in patients with node-negative or 1-3 node-positive rapidly proliferating breast cancer. Breast Cancer Research and Treatment, Springer Verlag. 2010; 125(3):775-8

30. Chow KKH, Hara W, Lim M, Li G. Combining immunotherapy with radiation for the treatment of glioblastoma. Neurooncol. 2015;123:459-64. 